сприяє покращенню якості математичних знань, підвищенню рівня навчальної мотивації, пізнавальної активності, формуванню більш високого рівня самооцінки. Уміння, характерні для критичного мислення, $є$ важливими для професійної діяльності майбутнього інженера.

\title{
Література
}

1. Бевз Г. П. Методика викладання математики: [навч. посібник] / Г. П. Бевз. [3-тє вид., перероб. і доп.]. - К. : Вища шк., 1989. - 367 с. 2. Бондаренко 3. В. Методика навчання інформаційних технологій розв'язування диференціальних рівнянь у технічних університетах: автореф. дис. на здобуття наук. ступеня канд. пед. наук: 13.00 .02 / Бондаренко Злата Василівна. - К., 2010. - 20 с. З. Журавлева Е. Г. Задачи как средство формирования умений критически мыслить у студентов математических специальностей педвузов: автореф. дис. на соиск. учен. степ. канд. пед. наук: специальность 13.00.02 / Журавлева Екатерина Геннадьевна. - Саранск: 2008. - 18 с. 4. Клочко В. І. Система задач як засіб формування професійно значущих знань 3 інформатики студентів економічних спеціальностей: [монографія]/ В. І. Клочко, Н. І. Праворська; Вінниц. нац. техн. ун-т. - Вінниця : УніверсумВінниця, 2008. - 139 с. 5. Слєпкань 3. I. Методика навчання математики: [підручник] / 3. І. Слєпкань. - К. : Вища шк., 2006. - 582 с. 6. Хачумян Т. І. Поняття «критичне мислення» та його сутність в психолого-педагогічній науці / T. I. Хачумян // Теоретичні питання культури, освіти та виховання: [зб. наук. пр.]. Вип. 24.- Ч. 2. - К. : Видавничий центр КНЛУ, 2003. - С. 171-177.

УДК 371.132:009

Карина Савченко

\section{УПРОВАДЖЕННЯ ПРОФЕСІЙНО-ПЕДАГОГІЧНИХ СИТУАЦЙ ЯК ЗАСОБУ РОЗВИТКУ КОМУНІКАТИВНИХ УМІНЬ МАЙБУТНІХ ВИХОВАТЕЛІВ ДОШКІЛЬНИХ ЗАКЛАДІВ}

Савченко К. Ю. Упровадження професійно-педагогічних ситуацій як засобу розвитку комунікативних умінь майбутніх вихователів дошкільних закладів.

У статті розкрито можливості впровадження професійно-педагогічних ситуацій як засобу розвитку комунікативних умінь майбутнього вихователя дошкільного закладу. Існуюча система професійної підготовки загалом і робота з формування комунікативних умінь у майбутніх вихователів потребують упровадження в навчальний процес вищої педагогічної школи нових, спеціально розроблених педагогічних ситуацій, які моделюють професійну діяльність вихователя дошкільного закладу та сприяють формуванню компонентів його професійної компетентності.

Ключові слова: професійно-педагогічні ситуації, комунікативні вміння, професійна підготовка вихователів, моделювання професійної діяльності, дошкільний заклад.

Савченко К. Ю. Внедрение профессионально-педагогических ситуаций как средства развития коммуникативных умений будущих воспитателей дошкольных учреждений.

В статье рассмотрены возможности внедрения профессионально-педагогических ситуаций как средства развития коммуникативных умений будущего воспитателя дошкольного учреждения. Существующая система профессиональной подготовки вообще и работа по формированию коммуникативных умений у будущих воспитателей нуждаются во внедрении в учебный процесс высшей педагогической 
школы новых, специально разработанных педагогических ситуаций, которые моделируют профессиональную деятельность воспитателя дошкольного учреждения и оказывают содействие формированию компонентов его профессиональной компетентности.

Ключевые слова: профессионально-педагогические ситуации, коммуникативные умения, профессиональная подготовка воспитателей, моделирования профессиональной деятельности, дошкольное заведение.

Savchenko K. Yu. Introduction of professional and pedagogical situations as a means of communication skills development among the future pre-school teachers.

The article studies possibilities of introducing professional and pedagogical situations as a means of communication skills development among the future pre-school teachers. The existent system of professional training and the work on forming communicative abilities among future teachers need introducing new specially developed pedagogical situations into the educational process of the higher pedagogical schools. These situations should simulate professional activity of a preschool teacher and assist in developing professional competence.

Key words: professional and pedagogical situations, communication skills, professional training of teachers, simulation of professional activity, preschool.

У сучасних умовах все більш гостро відчувається потреба в людях, які отримали професійні знання, володіють культурою мовного спілкування. Інтернаціоналізація відносин у діловому світі підвищує вимоги до якості навчання в умовах вищої школи і визначає необхідність пошуку шляхів удосконалення рівня комунікативного потенціалу випускників сучасних вищих навчальних закладах. Гуманістична спрямованість сучасної освіти потребує оновлення іiї змісту на всіх сходинках. Нині змінилось уявлення про мету освіти, що визначається як підготовка всебічно розвиненої творчої особистості, конкурентоспроможної на сучасному ринку праці, яка має успішно працювати у сфері будь-якої професійної діяльності. Сучасне зрушення в усвідомленні сенсу освіти вбачається в переорієнтації на розвиток здібностей студентів, а передача досвіду уподібнюється засобу чи матеріалу конструювання розвивальних процедур.

Різні аспекти формування комунікативної компетентності викликали увагу багатьох науковців. Певний інтерес становлять роботи авторів: Н. Анікеєва, А. Бодалєва, В. Кан-Калика, В. Семиченко та ін. Дослідження взаємовідносин викладача та студента, характеру педагогічної взаємодії в системі «учитель -учень», засобів гуманізації дидактичного спілкування здійснили такі науковці, як: Л. Кондрашова, Ю. Пассов, В. Скалкін, Е. Шубін, М. Уест та ін. Не менш цінними в науково-практичному плані $\epsilon$ спроби науковців виявити умови і засоби ефективного впливу на становлення комунікативної компетенції як важливого чинника, який впливає на рівень якості знань студентів. Вивчення сучасних психолого-педагогічних досліджень (С. Зеєр, М. Ігнатенко, І. Іпатов, М. Мазо, Г. Матушевська та ін.) свідчать про деякі спроби розв'язання питання формування комунікативної компетенції майбутніх спеціалістів засобами іноземної мови. Спеціальних досліджень, у яких розглядаються проблеми розвитку комунікативного потенціалу майбутніх фахівців засобами проектування професійних ситуацій у процесі професійно-педагогічний підготовці, у сучасний період недостатньо. Нечисленні публікації (М. Булигін, М. Вятютнєв, J. Beaucco, H. Besse, J. Cardinet, F. Danvers) 3 цього питання не надають повної картини досліджуваної проблеми. 
У зв'язку з цим актуалізується необхідність теоретичного обгрунтування проблеми формування комунікативних умінь студентів як важливого засобу становлення професіоналізму майбутнього вихователя дошкільного закладу. На сучасному етапі ми констатуємо низький рівень мовної культури майбутнього вихователя, недооцінку мови як засобу комунікації.

Проектування професійно-педагогічних ситуацій дозволяє врахувати особливості студентів, їх інтереси, розширює контекст діяльності, постає ефективним засобом створення мотиву до іншомовного діалогічного спілкування, сприяє реалізації сучасного підходу до навчання іноземної мови, коли в центрі уваги перебуває студент зі своїми інтересами і потребами.

Аналіз розвитку комунікативних умінь у студентів педагогічних ВНЗ дозволив виявити суперечності між потребою суспільства у фахівцях 3 високим рівнем розвитку комунікативного потенціалу, на основі якого вони будуватимуть стосунки у процесі навчання, та недостатньою теоретичною та практичною розробленістю питань, які розкривають механізм розвитку комунікаційного потенціалу в період навчання у вищий школі; необхідністю у висококваліфікованих фахівцях та невизначеністю теоретичних основ педагогічних умов процесу формування комунікативного потенціалу; вимогами до професійних якостей майбутніх вихователів дошкільних закладів і реальним рівнем підготовки їх до педагогічного спілкування.

Mema cmammi: розкрити можливості проектування професійно-педагогічних ситуацій як засобу розвитку комунікативних умінь майбутнього вихователя дошкільного закладу. Сучасна система професійної підготовки загалом і робота 3 формування комунікативних умінь у майбутніх вихователів потребують упровадження в навчальний процес вищої педагогічної школи нових, спеціально розроблених педагогічних ситуацій, які моделюють професійну діяльність вихователя дошкільного закладу та сприяють формуванню компонентів його професійної компетентності.

Ставлячи за мету пошук засобів формування професійної компетентності майбутніх вихователів дошкільних закладів, уважаємо доцільним побудову ієрархічно організованої системи педагогічних ситуацій. До іiї структури відносимо, насамперед, найбільш загальні ситуації, що визначають стратегію у формуванні професійної компетентності майбутнього вчителя: професійно-орієнтовані, особистісно зорієнтовані, комунікативно-орієнтовані та супідрядні з ними ситуації, що пов'язані 3 реалізацією цієї стратегії: навчальні, виховні, творчі й ігрові ситуації.

Професійно зорієнтовані педагогічні ситуації - це спеціально відібрані типові педагогічні ситуації, які можуть виникнути в реальній педагогічній дійсності і які вимагають від майбутніх педагогів здатності застосовувати набуті психологопедагогічні знання, засвоєні педагогічні вміння та навички, сучасні методологічні підходи, концептуальні ідеї, гнучкі інноваційні засоби та методи задля аналізу стану і прийняття рішення щодо необхідності певних заходів, спрямованих на отримання продуктивного результату у вигляді позитивних новоутворень в особистісній сфері та діяльності учня, та таких, які сприяють зростанню особистості й викликають у неї потребу в саморозвитку та самовдосконаленні [1].

У професійній підготовці майбутнього вихователя необхідно здобувати не лише професійний досвід, але й усвідомлювати досвід поведінки в життєвій ситуації, що потребує поряд із реалізацією когнітивного й практичного мислення, застосування особистісного потенціалу. Цій меті слугують особистісно зорієнтовані педагогічні cumуаціï. Такі ситуації, вважає В. Сєріков [4], не є особливим різновидом, а скоріше 
квінтесенцією виховних засобів загалом, їх сутнісною властивістю. Особистісно зорієнтовані ситуації спираються на розуміння особистості, яка здатна не розчинятися в ситуації, а вміє виходити, емансипуватися від неї, бути від неї незалежною, прагнути до іiі перетворення. У такій ситуації майбутній вихователь не вдається до примусу, маніпулювання, спонукання до наслідування, а перебуває в позиції суб'єкта. Він сам вирішує, спираючись на свій досвід, особистісні та професійні цінності, чому і як він має навчитися, які компоненти його професійної компетентності потребують удосконалення й розвитку [4].

Комунікативно зорієнтовані педагогічні ситуації $є$ спеціально розробленими навчально-педагогічними ситуаціями, які будуються на змісті комунікації, на комунікативних діалогах, що зорієнтовані на проблеми спілкування в системі «вчитель - учень», «учень - учень», «учитель - клас» як під час урочної, так і в позаурочній діяльності. Цінність таких ситуацій полягає у їх можливостях удосконалювати комунікативну компетентність майбутнього педагога, сприяти засвоєнню різних комунікативних позицій, соціальних ролей, розвитку емпатії [4].

Навчальні педагогічні ситуації- це спеціально відібрані типові педагогічні ситуації, що пропонуються майбутнім учителям задля вдосконалення професійних знань, поглиблення розуміння сутності закономірностей, принципів, концептуальних педагогічних ідей, формування педагогічних умінь i здібностей, здатностей їх застосовувати під час розв'язання практичних завдань. Поняття «виховні педагогічні cumyauіï» вважається більш широким, тому що вони спрямовані на аналіз чинників соціалізації особистості засобами навчально-виховного процесу. Ці ситуації можуть використовуватися як для моделювання реальних проблем виховання школярів, так i для самовиховання майбутнього вчителя.

Особливий клас утворюють творчі педагогічні ситуації, які виникають за наявності суперечності, проблеми, суперечності. Творча ситуація, на відміну від проблемної, не завжди забезпечує оволодіння новими знаннями, вміннями та навичками, але лише в такій ситуації можливе виявлення елементів професійної творчості майбутнього вихователя.

В основу ігрових педагогічних ситуацій покладено принцип рольової перспективи, який створює для кожного студента можливості виявити себе в новій, складній і відповідальній ролі. Рольові ситуації «студент - учитель», «учитель - клас» надають змогу набути майбутньому педагогові досвіду поведінки в обстановці, наближеній до професійно-педагогічної діяльності. Саме зміст ролі, її функціональні характеристики мають значення для формування професійної позиції майбутнього педагога, розвитку професійно значущих властивостей і якостей його особистості.

Упровадження професійно-педагогічних ситуацій можливе завдяки таким підходам: 1. Інтегрувати раніше набуті знання i вміння студентів, ураховувати міжпредметні зв'язки. 2. Відповідати темі заняття, мати зв'язок із практикою i життям, ураховуючи ціннісні соціокультурні пріоритети. 3. Орієнтуватися на формування у студентів складників професійної компетентності. 4. Реалізація матеріалів курсу «Педагогіка», «Історія педагогіки», «Методика виховної роботи» може здійснюватися через створення проблемно-пошукових ситуацій і використання активних методів навчання.

Розглянуті нами різновиди педагогічних ситуацій мають різний рівень узагальненості і складності (від репродуктивних, ілюстративних, частково-пошукових до проблемних, сюжетно-рольових, аналітико-синтетичних), вони сприяють розв’язання різних завдань професійно-педагогічної підготовки.

Наведемо приклади використання форм і методів формування комунікативних 
умінь засобами групової роботи.

Таблицяя 1

Форми та методи групової роботи та побудови взаємодії у групі

\begin{tabular}{|c|c|c|c|}
\hline $\begin{array}{l}\text { № } \\
\text { H/П }\end{array}$ & $\begin{array}{l}\text { Форма } \\
\text { групової } \\
\text { роботи }\end{array}$ & Характеристика & Результат \\
\hline 1 & Міні-лекція & $\begin{array}{l}\text { Коротке, стисле та } \\
\text { структуроване подання } \\
\text { інформації з проблеми. Може } \\
\text { супроводжуватись } \\
\text { ілюстраціями та груповими } \\
\text { обговореннями }\end{array}$ & $\begin{array}{l}\text { Підвищення рівня } \\
\text { інформованості учасників, } \\
\text { формування } \\
\text { проектувальних, } \\
\text { конструкторських, } \\
\text { організаторських навичок }\end{array}$ \\
\hline 2 & Презентація & $\begin{array}{l}\text { Спрощений та структурований } \\
\text { варіант міні-лекції, що містить } \\
\text { «точкову» ілюстровану } \\
\text { інформацію з конкретних } \\
\text { питань проблеми. Групові } \\
\text { обговорення бажані }\end{array}$ & $\begin{array}{l}\text { Підвищення рівня } \\
\text { інформованості учасників із } \\
\text { конкретних аспектів } \\
\text { проблеми, формування } \\
\text { зацікавленості в темі }\end{array}$ \\
\hline 3 & Міні-тренінг & $\begin{array}{l}\text { Коротке інтерактивне } \\
\text { практичне заняття, що містить } \\
\text { мінімум інформації та } \\
\text { максимум задіяності та } \\
\text { зворотного зв’язку учасників }\end{array}$ & $\begin{array}{l}\text { Формування окремих } \\
\text { навичок і вмінь; отримання } \\
\text { практичних знань }\end{array}$ \\
\hline 4 & Тренінг & $\begin{array}{l}\text { Інтерактивна форма роботи, } \\
\text { спрямована на формування } \\
\text { низки практичних компетенцій } \\
\text { iз певної проблеми }\end{array}$ & $\begin{array}{l}\text { Формування компетенцій, } \\
\text { отримання практичних } \\
\text { знань }\end{array}$ \\
\hline
\end{tabular}

Так, міні-лекція надає можливість учасникам опанувати теорію у максимально можливому обсязі за короткий проміжок часу. Успішність проведення міні-лекції зумовлена ступенем сформованості у ведучого низки навичок: проектувальних, конструкторських, організаторських [3, с. 79-81]. Проектувальні навички виявляються у здатності викладача: спланувати лекцію з урахуванням спеціальності учасників; передбачити можливі утруднення учасників у засвоєнні матеріалу; знайти методи та методичні прийоми, необхідні для подолання труднощів учасниками; визначити найраціональніші види діяльності учасників; сприймати й ураховувати реакцію учасників на своє викладення і перебудовувати його в подальшій діяльності; встановити зв'язки лекції 3 представленою учасниками спеціальністю. Конструкторські навички передбачають: відбір матеріалу для одного заняття; виділення вузлових понять i закономірностей; віднайдення правильного співвідношення нормативного та теоретичного матеріалу на конкретному занятті; планування логічних переходів від одного етапу занять до іншого; розташування теоретичного матеріалу від легкого і простого до важчого і складнішого; визначення висновків за певною темою й перехід до наступної; передбачення стомленості аудиторії та підготування до позбавлення напруження у групі. Організаторські навички виявляються в наявності у викладача навичок організовувати свій час, індивідуальну та групову роботу учасників, взаємодію з ними під час роботи тощо.

Під час констатувального експерименту було встановлено недостатність ступеня впровадженості в навчальний процес різновидів педагогічних ситуацій, завдань i задач, що використовуються 3 метою формування компонентів професійної 
компетентності майбутнього вихователя дошкільного закладу. Більшість опитаних вихователів (62\%) педагогічні ситуації на заняттях використовують час від часу, а $9 \%$ - майже ніколи їх не застосовують. Наявна недооцінка моделювання педагогічних ситуацій як ефективного засобу професійного становлення майбутнього вихователя; відсутність єдиного підходу до структурування змісту професійно важливих знань, класифікацій методичних прийомів і педагогічних технологій, що застосовуються на заняттях у вищий педагогічній школі.

Порівнюючи результати констатувального і формувального експериментів, ми переконалися в ефективності запропонованої нами програми занять, на яких використовувалися педагогічні ситуації, створюють необхідні умови задля підвищення якості знань студентів. Ефективним методом у формуванні комунікативних умінь висловлювати власні думки $\epsilon$ «Мозкова атака»- методи колективного розв'язання проблеми. Перед студентами ставилася окрема ситуація, яка вимагала обговорення й виявлення можливих шляхів її розв'язання. Кожна версія розглядалася окремо, обов'язково виокремлювалися переваги та недоліки. Кінцевий результат - обиралася найбільш вдала думка.

Отримані результати пояснюються низкою труднощів, зумовлених як соціальноекономічними, так і суб'єктивними чинниками навчально-виховного процесу педагогічного ВНЗ. 3-поміж них: недостатнє професійне педагогічне спрямування навчальних курсів кожного зі складників підготовки, підвищена вага фундаменталізації змісту підготовки, відсутність міжпредметної координації і співпраці у становленні цілісної особистості майбутнього вихователя; неусвідомлення суб'єктами професійної підготовки (викладачами і студентами) професійної компетентності як системної якості; недооцінювання засобів моделювання педагогічних ситуацій на всіх етапах і напрямах професійної підготовки, відсутність широкого вибору майбутніми вихователями траєкторій професійного й особистісного розвитку. Перспективу роботі ми вбачаємо у розробленні професійних ситуацій та завдань, спрямованих на формування проектних умінь студентів.

\section{Література}

1. Дубасенюк О. А. Професійно-педагогічні задачі: типологія та технологія розв'язання : [навч. посіб. для студентів вищих навчальних закладів]/ О. А. Дубасенюк, О. В. Вознюк. - Житомир : Вид-во ЖДУ ім. І. Франка, 2010. - 272 с. 2. Луговий В. Європейська концепція у вищій школі та проблеми іiі реалізації в Україні компетентнісного підходу / В. Луговий // Реалізація європейського досвіду компетентнісного підходу у вищій школі України: [матеріали методологічного семінару]. - К. : Педагогічна думка, 2009. - С. 5-10. 3. Освітні технології: [навч.метод. посіб. / за заг. ред. О. М. Пєхоти]. - К. : А.С.К., 2001. - 256 с. 4. Сериков В. В. Личностно ориентированное образование: поиск новой парадигмы : [монография] / Владислав Владиславович Сериков. - М. : Логос, 1998. - 350 с.

УДК 378 : 005.6

Лариса Савченко

\section{АНАЛІЗ НОРМАТИВНИХ ДОКУМЕНТІВ ПІДВИЩЕННЯ ЯКОСТІ ОСВІТИ МАЙБУТНІХ УЧИТЕЛІВ ТЕХНОЛОГІЇ І КРЕСЛЕННЯ ЗАСОБАМИ ПЕДАГОГІЧНОЇ ДІАГНОСТИКИ}

Савченко Л. О. Аналіз нормативних документів підвищення якості освіти майбутніх учителів технології і креслення засобами педагогічної діагностики.

У статті проаналізовано навчальні плани, освітні стандарти щодо підготовки 